\title{
False-positive test results for syphilis in relatives of a patient with systemic lupus erythematosus
}

\author{
SUSAN JESSOP AND PHYLLIS BOTHA \\ From the Departments of Dermatology, Rheumatology, and Bacteriology, University of Cape Town and \\ Groote Schuur Hospital, South Africa
}

SUMMARY In a family of nine members, two had systemic lupus erythematosus and seven positive serological test results for syphilis. None of the affected subjects had a history or physical signs of syphilis, but two had positive results to the Treponema pallidum immobilisation test. The explanation for these findings is not known, but possibly they were all false-positive reactions.

\section{Introduction}

Familial aggregation of systemic lupus erythematosus (SLE) is widely reported and has been reviewed by Masi (1968), who found an incidence of $1-2 \%$ in first-degree relatives of patients with SLE. The reason for this finding is not clear, but it is probable that both genetic and environmental factors play a role. Humoral abnormalities are found in about $10 \%$ of first-degree relatives, the most common being hypergammaglobulinaemia, rheumatoid factor, antinuclear antibody, and false-positive lipoid test results for syphilis (Morteo et al., 1961.)

We report a family in which two members had SLE and seven of the other eight had positive results to serological tests for syphilis, including the fluorescent treponemal antibody test (FTA-ABS) and the Treponema pallidum haemagglutination (TPHA) test.

\section{Material and methods}

\section{SEROLOGY}

The Venereal Disease Research Laboratory (VDRL) test followed a standard method (Communicable Disease Center, 1969). The FTA-ABS test was performed as described by Hunter et al. (1964) and the TPHA test as described by Johnston (1972).

\section{PATIENTS}

Case 1

A 50-year-old women presented in 1974 with a large leg ulcer of 27 years' duration. She was found to have Address for reprints: Dr S. Jessop, Department of Dermatology,
Groote Schuur Hospital, Cape Town, South Africa

Received for publication 12 October 1978 thinning of the scalp hair, discoid lupus erythematosus, polyarthritis, and mouth ulcers. On investigation her haemoglobin was $11 \cdot 2 \mathrm{~g} / \mathrm{dl}$, white cell count $2.7 \times 10^{9} / 1$, with normal hepatic and renal function. The LE-cell test gave a positive result, the antinuclear antibody was present at a titre of $1 / 500$, the VDRL test gave a positive result at a titre of $1 / 2$, and the FTA-ABS test gave a positive result with a homogeneous pattern. Her symptoms improved with rest in bed and the administration of salicylates. She remained well until May 1977, when she was admitted in a stuporose state and died, probably of cerebral lupus.

\section{Case 2}

The 29-year-old daughter of Case 1 presented in 1977 with severe haemolytic anaemia, positive results to the LE-cell test, and antinuclear antibody at a titre of $1 / 100$.

Because of our interest in familial aggregation of lupus, we then examined the siblings of Case 2. Our findings are summarised in the Table. None of the subjects had a history or physical signs suggesting a connective tissue disease or syphilis, but seven of the eight tested showed some abnormality in the serological test results for syphilis. Two subjects had a positive result to the Treponema pallidum immobilisation (TPI) test. None had received recent antibiotic therapy.

\section{Discussion}

The family which we describe is not unusual in having two members with SLE. The occurrence of false-positive reactions in family groups is less well known and has been reviewed by Putkonen and Lassus (1965), who reported two families with an 
Table Results of serological tests in siblings of Case 2 for SLE and syphilis

\begin{tabular}{|c|c|c|c|c|c|c|c|}
\hline \multirow[b]{2}{*}{ Sibling } & \multirow[b]{2}{*}{ Year of birth } & \multicolumn{6}{|c|}{ Test results } \\
\hline & & $A N A$ & $\mathrm{CH}_{50}$ & $V D R L$ & $F T A-A B S$ & $T P I$ & TPHA \\
\hline 1 & 1925 & $1 / 500$ & 119 & $1 / 1$ & ND & ND & + \\
\hline 2 & 1947 & - & 149 & - & B & ND & - \\
\hline 3 & 1948 & $1 / 100$ & 70 & - & - & $6 \%$ & - \\
\hline 4 & 1949 & - & 137 & - & B & ND & - \\
\hline 5 & 1950 & - & 172 & $1 / 1$ & B & $55 \%$ & + \\
\hline 6 & 1954 & - & 175 & - & - & ND & - \\
\hline 7 & 1957 & - & 147 & - & + & ND & + \\
\hline 8 & 1959 & - & 154 & - & B & $9 \%$ & + \\
\hline 9 & 1961 & - & 172 & $1 / 8$ & + & $93 \%$ & + \\
\hline 10 & 1966 & - & 161 & $1 / 1$ & + & $8 \%$ & + \\
\hline
\end{tabular}

+ positive - negative

ANA $=$ antinuclear antibody

$\mathrm{CH}_{50}=$ total haemolytic complement (normal 160-210)

$\mathrm{ND}=$ not done

$\mathrm{B}=$ borderline

aggregation of false-positive reactors, one of the affected subjects having rheumatoid arthritis. Kostant (1972) later described a further two families, including one in which three generations were affected. Tuffanelli (1968) examined 103 falsepositive reactors and their 199 relatives and found a high incidence of antinuclear antibody, rheumatoid factor, and hypergammaglobulinaemia. He suggested that this implied an inherited defect in immunoglobulin control mechanisms, and this could help to explain the familial aggregation of both falsepositive reactors and SLE.

It seems possible that the family we describe has a hereditary abnormality associated with false-positive serology and a predisposition to develop SLE, the abnormal serology being a marker of the 'lupus diathesis'. A study (Lowenstein and Rothfield, 1977) of related and unrelated household members showed a higher incidence of antinuclear antibody in related persons but more household members with positive immunofluorescent findings on skin biopsy. This supports the view that both genetic and environmental factors could be concerned in the pathogenesis of SLE.

The serological tests for syphilis (Jaffe, 1975) fall into two groups, the treponemal and the nontreponemal. The latter, including the VDRL test, use non-specific cardiolipin as antigen and may give a positive result in a wide range of conditions, including viral illnesses, malaria, leprosy, and the connective tissue disorders. In a study of 110 chronic false-positive reactors, Johansson (1971) found that 30 had probable or definite SLE and 25 were completely normal. It was initially thought that the treponemal tests were specific for syphilis, but this has not proved to be the case, $15-23 \%$ of patients with SLE having a false-positive result to the FTAABS test (Shore, 1976). In SLE this reaction may take the form of a beaded (Kraus et al., 1970) or a homogeneous fluorescence, the latter being indistinguishable from the true positive (Shore and Faricelli, 1977). The atypical, beaded pattern appears to be due to the presence of anti-DNA antibody in the serum (Kraus et al., 1971) but the factor responsible for the homogeneous FTA-ABS test has not been identified. The TPHA test may be even less specific in some laboratories. Garner et al., (1973) applied the test to 274 subjects with false-positive reaginic test results but negative FTA-ABS test results, and found $11 \cdot 3 \%$ to give positive results to the TPHA test.

The TPI test is thought to be highly specific for syphilis, although its results may become negative if the patient is treated early in the disease (Lassus, 1968). Moore and Mohr (1952), examining a group of people thought to be false-positive reactors, found $16 \%$ to have positive results to the TPI test. They concluded that clinical judgement was probably at fault rather than the test, but they were, of course, unable to prove this.

The positive results to the TPI test in two of our subjects raise the question of possible false-positive results to this test. The only recognised false-positive reaction is that seen when the patient is taking an antibiotic, but this was not the case in our subjects. Another possibility, which cannot be completely excluded, is that two members of the family had had syphilis and four others had false-positive results to serology. Both venereal and endemic syphilis commonly occur in the small rural communities of South Africa (Du Toit, 1969). Du Toit found, however, that nasopharyngeal ulceration, mucous patches, condylomata lata, gummata, and bone lesions were common in endemic syphilis, and our subjects had none of these.

The most likely explanation for our findings is that the members of the family described above had a variety of serological abnormalities which gave rise to 
false-positive results to the VDRL, FTA-ABS, TPHA, and TPI tests in certain members and to SLE in two cases.

We are indebted to $\mathrm{N}$. Richardson and $\mathrm{H}$. J. Koornhof, of the South African Institute for Medical Research, for the TPI tests, to Dr D. Whitelaw for assistance in collecting blood samples, and to $\mathrm{Dr} \mathrm{H}$. Brown and Professor W. Gordon for access to their patients. One of the authors (SJ) is in receipt of a grant from the Arthritis Foundation, Cape.

\section{References}

Communicable Disease Center (1969). Manual of Tests for Syphilis. Edited by the US Department of Health, Education and Welfare. PHSP Publication No. 411. US Government Printing Office: Washington, DC.

Du Toit, J. A. (1969). Endemic syphilis in the Karoo. South African Medical Journal, 43, 355-358.

Garner, M. F., Backhouse, J. L., Daskalopoulos, G., and Walsh, J. L. (1973). The Treponema pallidum haemagglutination (TPHA) test in biological false positive and leprosy sera. Journal of Clinical Pathology, 26, 258-260.

Hunter, E. F., Deacon, W. E., and Meyer, P. E. (1964). An improved FTA test for syphilis, the absorption procedure (FTAABS). Public Health Reports, 79, 410-412.

Jaffe, H. W. (1975). The laboratory diagnosis of syphilis. Annals of Internal Medicine, 83, 846-850.

Johansson, E. A. (1971). Clinical and factorial evaluation of 110 CBFP reactors. Acta Dermato-venereologica, 51, S65, 1-37.
Johnston, N. A. (1972). Treponema pallidum haemagglutination test for syphilis: Evaluation of a modified micro-method. British Journal of Venereal Diseases, 48, 474-477.

Kostant, G. H. (1972). Familial chronic biologic false-positive seroreactions for syphilis: report of two familiss, one with three generations affected. Journal of the American Medical Association, 219, 45-48.

Kraus, S. J., Haserick, J. R., and Lantz, M. A. (1970). Atypical FTA-ABS fluorescence in lupus erythematosus patients. Journal of the American Medical Association, 211, 2140-2141.

Kraus, S. J., Haserick, J. R., Logan, L. C., et al. (1971). Atypical fluorescence in the fluorescent treponemal antibody (FTA-ABS) test related to deoxyribonucleic acid (DNA) antibodies. Journal of Immunology, 106, 1665-1669.

Lassus, A. (1968). Treponemal and lipoidal tests in old treated syphilis. Acta Dermato-venereologica, 48, S60.

Lowenstein, M. B., and Rothfield, N. F. (1977). Family study of systemic lupus erythematosus. Analysis of the clinical history, skin immunofluorescence and serologic parameters. Arthritis and Rheumatology, 20, 1293-1303.

Masi, A. T. (1968). Population studies of the rheumatic diseases. Edited by P. H. Bennet and P. H. N. Wood, p 267. In Proceedings of the Third International Symposium, New York. International Congress Series No. 148, Excerpta Medica Foundation: Amsterdam.

Moore, J. E., and Mohr, C. F. (1952). Biologically false-positive serologic tests for syphilis. Journal of the American Medical Association, 150, 467-473.

Morteo, O. G., Franklin, E. C., McEwan, C., et al. (1961). Studies of relatives of patients with systemic lupus erythematosus. Arthritis and Rheumatology, 4, 356-363.

Putkonen, T., and Lassus, A. (1965). Familial occurrence of chronic biologic false-positive seroreactions for syphilis. Dermatologica, 130, 332-339.

Shore, R. N. (1976). Lupus erythematosus and reactive tests for syphilis. Cutis, 17, 745-748.

Shore, R. N., and Faricelli, J. A. (1977). Borderline and reactive FTA-ABS results in lupus erythematosus. Archives of Dermatology, 113, 37-41.

Tuffanelli, D. L. (1968). False-positive reactions for syphilis Archives of Dermatology, 98, 606-611. 